\title{
THE ROAD TO SERFDOM AGAINST THE GREAT TRANSFORMATION: A COMPARISON WITH REFERENCE TO UNINTENDED CONSEQUENCES
}

\author{
Hüseyin ÖZEL \\ Hacettepe Üniversitesi, İ̈BF Öğretim Üyesi, ozel@ hacettepe.edu.tr
}

Başvuru Tarihi/Application Date: 16 Temmuz 2019

Kabul Tarihi/Acceptance Date: 30 Kasim 2019

\section{ÖZET}

$\mathrm{Bu}$ çalışma, 1930'larda Avrupada faşizm ile sosyalizmin gelişimini açıklama amacını güden iki yapıt1, Karl Polanyi'nin Büyük Dönüşüm kitabı ile Friedrich A. Hayek'in Kölelik Yolu kitabını, "niyetlenilmemiş sonuçlar" argümanı çerçevesinde karşılaştırma amacı gütmektedir. Genel olarak bireysel eylemin nasıl olup da bir sosyal düzene, ya da onun yıkılışına yol açtığını dikkate alan bu argüman, sosyal teorinin ayrılmaz bir parçası olarak kendini göstermektedir. Bu bakımdan bu iki yazarın aynı argümanı, birbirine tümüyle karşıt sonuçlara ulaşan iki farklı anlayışı geliştiriken kullanmaları ilginç görünmektedir. Bununla birlikte, çalışmada, ilk olarak bu argümanın, özellikle Hayek'te etkin bir sosyal düzeni yaratma "görevini" yerine getiremediği, buna karşıllk Polanyi'de daha somut bir düzeyde, sosyal düzenin çelişki ve kurumsal gerilimlerini ortaya koymada daha başarılı olduğu ileri sürülmektedir. Yine de, çalışmanın ikinci bir iddiası, niyetlenilmemiş sonuçlar argümanının kendi başına bir sosyal teori oluşturmak için yeterli olmadığı ve iki düşünür arasındaki temel farkın, insan ve özgürlüğü hakkındaki benimsedikleri "vizyonlar" olduğu ileri sürülmektedir.

Anahtar Sözcükler: Karl Polanyi, Friedrich A. Hayek, Niyetlenilmemiş Sonuçlar, Büyük Dönüşüm, Kölelik Yolu

\section{ABSTRACT}

The present paper attempt at comparing two opposite accounts, developed to explain the same phenomenon, the rise of fascism and socialism in Europe in the 1930s, namely, Karl Polanyi's The Great Transformation, and Friedrich A. Hayek's The Road of Serfdom, in reference to the notion of the "unintended consequences." The idea of unintended consequences, postulates, as an answer to the problem of "order" that even though the actions of individual human beings are carried out on their intentions, they will have some consequences that were not intended by any of these individuals, is taken as a reference point because both Polanyi and Hayek use this idea as an important ingredient of their social theories. However, it is argued in the paper firstly that the idea of unintended consequences cannot fulfil its promise, namely to explain the social order, especially in Hayek's case. In Hayek, it remains essentially a mere abstraction and reduces to a functional argument based on the "representative individual" whereas in Polanyi it was conceived in terms of interactions between individuals who belong to different sections of the society, and thus it is helpful in presenting the institutional strains and contradictions of capitalism on a more concrete level. But, secondly, it is argued that it is not the differences in the use of the idea of unintended consequences per se but the difference between the respective visions of these two thinkers, concerning human beings and freedom, which actually constitutes the essential, unbridgeable gap between their social theories.

Keywords: Karl Polanyi, Friedrich A. Hayek, Unintended Consequences, The Great Transformation, The Road to Serfdom. 


\section{Introduction}

Albert O. Hirschman (1982), in an interesting article, compares different theses regarding the working of the capitalist system and argues that the two basic but contradictory positions maintained in these theses apply equally well to the system. That is, capitalism is both "self-reinforcing" and "self-undermining" at the same time. But all of these theses, interestingly, in some way or another employ the hypothesis of unintended consequences of intentional human action as an explanatory mechanism. This observation can easily be generalized. At least since Adam Smith, if not Bernand Mandeville (1962), the idea of unintended consequences, in the sense that although the actions of individuals are intended in nature, some of the consequences that follow from these actions give rise to the emergence of an "order" that nobody intends to create, has been an integral part of social theory, irrespective of its specific form. At a general level, alternative and often incompatible social theories, whether it was developed by Karl Marx or by Friedrich A. Hayek, can be observed to be founded on such a hypothesis, appearing, of course, with some variations. Even as an ardent liberal as Karl Popper says that Karl Polanyi once suggested to him that "it was Marx who first conceived social theory as the study of unwanted social repercussions of nearly all our actions" (Popper 1950, $668 \mathrm{n}$ ).

In the present paper, I will be dealing with the idea of unintended consequences by considering two alternative, and almost diametrically opposite, accounts concerning the market system: that of Karl Polanyi, as developed in his The Great Transformation (hereafter GT), and that of Friedrich A. Hayek, as developed in his The Road to Serfdom (hereafter $R S$ ), both of which were published at the same time, i.e., the end of the Second World War. The reason for such a comparison is, first of all, that both books seek to explain the same phenomenon: the rise of fascism and all forms of "collectivism," including socialism in Europe during the 1930s. More importantly, both books use, I argue, not only similar models to explain the working of capitalism, but, even more interestingly, similar social-theoretic positions founded on the hypothesis of unintended consequences.

The present paper is based upon the conviction that the unintended consequences argument by itself cannot constitute a demarcation line between an individualist social theory and a "collectivist" one, Hayek's view notwithstanding; and it takes Polanyi's and Hayek's positions as particular instances which confirm this conviction. The idea of unintended consequences is a general hypothesis that is valid only at the most general level, i.e., it is not an explanatory mechanism per se. Without an understanding how it works at particular, concrete instances, this general hypothesis cannot be strong enough to sustain the whole of a social theory, be it individualist or "collectivist." Nevertheless, in regard of Polanyi's and Hayek's social theories, it should be stressed that the distinguishing character of their social theories is not how they handle the unintended consequences, but their respective "visions" of the market society: While for Polanyi, it is the prevalence of the "market mentality" arising out of the institutional structure of capitalism which is responsible for the ultimate annihilation of freedom and disintegration of society, such an institutional structure for Hayek actually secures personal freedom. This position of Hayek's stems from his belief that the human sphere is conditioned by scarcity and its result, choice, and such a belief requires an "economistic" framework, to use Polanyi's word. On the other hand, Polanyi can be said to be under the influence of "economophobia," $(R S, 222)$ to use this time Hayek's word, who denies the importance of scarcity and choice for the human condition. Thus, it is this difference of understanding of the human condition which gives rise to the antagonism between the two authors. In order to see this, it might be helpful to outline the "Invisible Hand" theory whose basic ingredient is the unintended consequences hypothesis.

\section{2. "Invisible Hand" as a Social Theory ${ }^{1}$}

The notion of the "Invisible Hand" is generally used in the liberal economic tradition in relation to both the problem of resource allocation, and the problem of a stable social order. These two dimensions of the notion is a key in delimiting the discipline of economics, ever since Adam Smith

\footnotetext{
${ }^{1}$ This section is based on Özel (2009).
} 
had put forward it. The Invisible Hand approach not only maintains that in market economies, the coordination between different decision-making agents is spontaneously established without any need for another authority, but also argues that this harmony can generate a sustainable stable economic and social order, even though not intended or desired by anybody. In this respect, Adam Smith deserves as a "founding father" of not only economics, but also other social sciences. The reason is that Smith was one of the first philosophers who was successful to present a satisfactory answer to the problem of "order," which is still with us. As a matter of fact, it can even be argued that since Smith, the answer to the question of social cohesion in modern societies, that is, the hypothesis of "unintended consequences of intentional human action", has hardly changed (Giddens 1984, 9$14)$.

Smith's challenge was to find a way of reconciling individual "virtues" and their self-interest on the one hand and, individual interests and social order and well-being on the other hand. In The Wealth of Nations, he argued that the "system of natural freedom" would emerge as a consequence of people acting in their own self-interest; individuals, while pursuing their own interests, increase social welfare as well. The Invisible Hand implies that the social order emerges "spontaneously," as Hayek would say, as an outcome of the tendency to exchange and social division of labor. Invisible Hand can solve the "problem of order" without any need for outside intervention or an authority. This "spontaneous order" does not emerge by force; quite the reverse, it an exchange activity based on the self-interest motive. The functioning of such system relies on freedom of individual enterprise and free competition. There is no need for intervention of the state or any other authority for the smooth operation of the order; as a matter of fact, such intervention will not only have a deteriorating effect on resource allocation, but will also eliminate individual freedom, the most precious value (Hayek, 1944). In short, there is no conflict but harmony between the individual's self interests and the interests of society.

As a general social theory model, the Invisible Hand metaphor encompasses two basic mechanisms or processes (Ullmann-Margalit 1997, 181-99): Firstly, Invisible Hand should have a "filtering mechanism," which keeps out all beings, impacts or processes that might ruin the achievable pattern. Secondly, as each piece or element will also affect the harmonization of other pieces or other elements while adopting local changes, Invisible Hand should contain an "equilibrating mechanism," which ensures the generation of a specific pattern as a consequence of all harmonization processes. The simultaneous functioning of these two mechanisms not only exclude the impacts that might ruin the order, but they also assure the emergence of a specific pattern as an outcome of very different incidents that seem completely unrelated to one another in an anticipated or intended manner. As it is known, these two mechanisms, which are employed chiefly in economics and social theory, are rational choice theory and equilibrium mechanism. The actions of numerous individuals, who pursue their own divergent interests, combine to bring about a well-structured yet undesigned structure. However, such supposition is nothing other than the preassumption of the consequence. The reason is that a functionalist and/or teleological approach adds an "explanatory" dimension to Invisible Hand: The primary function of Invisible Hand is to ensure optimal resource allocation and a stable social order. However, not presenting, but merely assuming these causal mechanisms is not an "explanation". For example, such kind of reasoning reminds us of Hegel's famous notion of the "The Cunning of Reason" (Sarfati, 2007). ${ }^{2}$ Even if individuals seem to act of their own free will, there might actually be some "cosmic" forces, whose existence they are unaware of, that lead them towards achieving a more noble goal. Such an explanation, which claims that individuals are in fact nothing but puppets to be employed for attaining certain goals, will guide us either to a Hegelian kind of metaphysical teleology, or at least to functional "explanations" that link the cause of the existence of the whole economic and social system to the fulfillment of certain functions. Another problem is that especially liberal approaches employ teleology or functionalism to support their proposition that the

\footnotetext{
${ }^{2}$ Yet Edna Ullmann-Margalit (1997) states that Invisible Hand and the Cunning of Reason should not be mistaken for each other and argues that Hegel used the notion of the 'Cunning of Reason mostly for explaining the behavior of historical personalities, who shaped history.
} 
system always produces the best results. That is to say, this notion might make us adopt Dr. Pangloss's viewpoint, who, as a caricature of philosopher Leibniz (Russel 1945, 581), argues that "this world is the best of all possible worlds."

Such teleological or functionalist explanations argue that any being, organism, system, institution or social practice exists because of their function in the first place. In other words, the "explanation" for the functioning of the system involves the achievement of preset goals or functions. In social sciences, functionalism argues that social systems have certain "needs," therefore it should be decided how societies or social systems will meet these needs. How any component of society can create the conditions that would be helpful for a more extensive system is still among the basic questions, to which functionalism seeks an answer (Hollis 1994, 95-100; Giddens 1984, 293-97; Little 1991, 91-93; Mahner and Bunge, 2001). Yet, a social component, practice or system's fulfillment of some functions does not explain how the component, practice or system in question emerged in the first place. ${ }^{3}$ Functionalism may be helpful in explaining the working of artificial systems designed for attaining specific goals via characteristics or processes, some of which are chosen; however, Invisible Hand clearly rejects the existence of such kind of design.

A most frequent strategy to justify the argument of the invisible hand is to invoke methodological individualism, and Hayek is no doubt a most well-known champion of this strategy. In his famous "Scientism and the Study of Society" articles (Hayek, 1942 and 1943a), he argues that social science deals with the unintended consequences of intentional individual behavior and its repercussions, and that the proper method, therefore, for the social science is methodological individualism (Hayek 1942, 284, 288). As to unintended consequences, he says:

If social phenomena showed no order other except in so far as they were consciously designed, there would indeed be no room for theoretical sciences of society and there would be, as is often argued, only problems of psychology. It is only in so far as some sort of order arises as a result of individual action but without being designed by any individual that a problem is raised which demands a theoretical explanation." (Hayek 1942, 288)

And, as to the methodological individualism, he argues: "It is not the whole of the individual minds in all their complexity, but the individual concepts, the views of people have formed of each other and the things, which form the true elements of the social structure" (Hayek 1942, 284), and immediately adds: "The individuals are merely the foci in the network of relationships and it is the various attitudes of the individuals towards each other (or their similar or different attitudes towards physical objects) which form the recurrent, recognisable and familiar elements of the structure" (Hayek 1942, 284).

Methodological individualism (Giddens 1984, 214; Little 1991, 183-88) refers to a reduction of the explanation of all large entities, i.e. social phenomena, systems or relationships, by reference to smaller ones without loss of meaning. Even some individualists argue that terms such as "society" or "social system" only refer to abstract, fictional models used by researchers for making their postulations easy to understand. In the most general term, methodological individualism maintains that some beings, characteristics and particularly forces such as society and social relations can be explained via their components like individuals, or they can be presupposed based on the behavior of these components.

Assuming that an individual is the ultimate explanatory category, the Invisible hand model is founded on "representative individuals", who are not different from one another; whose main form of interaction in the market is exchange relations and each of who displays optimization behavior

\footnotetext{
${ }^{3}$ Another factor that makes this situation more complicated is that same institution can fulfil more than one function. Besides, according to Karl Polanyi, this is a rule rather than an exception: "no institution ever survives its functionwhen it appears to do so, it is because it serves in some other function, or functions, which need not include the original one" (Polanyi 1944, 183).
} 
(Kirman, 1992). Undoubtedly, this understanding neither refers to social and institutional contexts, where individual behavior takes place, nor to social interactions between individuals. Individuals are solely expected to behave so as to pursue their own interests similar to the gears that have to work in a particular manner. Thus, the possibility of non-optimal consequences such as inefficiency in resource allocation or social conflicts is eliminated at the very beginning. But, the achievement of unintended consequences does not always assure Panglossian consequences. On the other hand, these two hypotheses are jointly used in Invisible Hand's mechanical conceptualizations and therefore, for instance, the thought of the possibility that the functioning of the system might produce tendencies that might hinder its smooth operation is totally excluded as it will contradict with such functionalist or teleological explanations. ${ }^{4}$

In conclusion, the efforts towards filling the content of the Invisible Hand metaphor with functional or teleological "causal" mechanisms have caused two important problems in respect of the methodology (Rothschild 1994, 319-321): Firstly, this notion, which is based on the "representative individual" construct, overlooks idiosyncracies among individuals as well as differences in responses to the same effects on the part of different individuals and sections of the society. The Invisible Hand approach assumes that all decision-making agents (or "organisms") act only to perform a specific function. Secondly, even though metaphysical consequences like "the cunning of reason", or religious outcomes like "creation" are avoided, the optimization understanding that lies behind the Invisible Hand approach will eventually lead to a Panglossian state, which will result in the exclusion of nonoptimal states from the very beginning. Therefore, all these efforts to provide Individual Hand with a causal mechanism cannot produce any other result but the preassumption of a state that needs an explanation. So, abandoning such a "Panglossian" approach and adopting disequilibrium and nonoptimal states will not only provide Invisible Hand with a causal context, but will also allow for a more realistic conceptualization in economics and social theory. In order to understand Now, after this methodological note, we can start comparing two books on the basis of the notion of unintended consequences.

\section{Polanyi's The Great Transformation ${ }^{5}$}

\subsection{Fictitious Commodities and the Separation of "Economic" from "Political"}

Karl Polanyi's The Great Transformation is primarily a critique of capitalism, or what he calls the "market economy," itself. The overall argument of the book is that "the nineteenth-century civilization" disintegrated not as the result of some external causes, like invasion or revolution, but as the result of "the measures which society adopted in order not to be, in its turn, annihilated by the action of the self-regulating market" $(G T, 249)$. According to Polanyi, it is in general impossible to form an economic system according to the prescriptions given by the utilitarian outlook concerning human societies, an outlook which is based upon the "invisible hand" paradigm and its basic ingredient, the principle of laissez-faire; such a "self-regulating" economic system, to be established on the basis on the motive of individual gain and the fear of hunger is "in the very nature of things impossible" $(G T, 269)$. This impossibility reveals the fact that the institutional structure upon which the market system is founded is self-undermining and gives the capitalist society its unstable character.

\footnotetext{
${ }^{4}$ Another line of defense for the invisible hand argument is to use an evolutionary approach, and the most vigorous defender of the evolutionary approach in economics was unquestionably Hayek himself again (Hayek, 1967, 1973, 1976, 1979), even if the present paper does not consider this aspect of Hayek's work, for it limits itself with his arguments in the Road to Serfdom. For an inclusive criticism of Hayek's views on evolution, see Hodgson (1993, Chapter 12). However, the use of evolution does not prevent his approach, or any other argument based on the mechanisms of evolution for that matter, from falling into functionalism, or an 'adaptationist' evolutionary approach (Gould and Lewontin 1979, 581-98; Lewontin 1991, 145-46) and Lewontin (2007). For a critique of the use of evolutionary notions and mechanisms in the social science and economics, see Güzel and Özel (2011).

5 This section is based on Özel (1997).
} 
Polanyi's analysis can be seen as formed by three main analytical components: the creation of the three "fictitious commodities," the institutional separation between the market and the "rest of the society"; and the "double movement" (Özel 2019, 132). The first two aspects define the institutional structure of the market society whereas the last component provides us with the mechanism of the "social collapse." The establishment of the market system required the creation of the three "fictitious commodities," namely, labor, land and money, and this creation gave rise to an institutional separation between the "economic" and the "political" spheres. The "self-regulating market," in the sense of its being subject to the "laws of supply and demand" (Polanyi 1957, 68) needs no intervention from the "political" sphere in order for it to function smoothly. This forces individuals to live through a separated life; on the one hand, in the market, they are to be guided by the "motive of gain and the fear of starvation" (Polanyi 1947, 113), and on the other, they are to be "political animals," the social being proper, who are concerned with achieving a "good life" in the Aristotelian. That is to say, the institutional structure of the market system forces human beings to live through a separate, fragmented life; in other words, under capitalism the "totality" of human existence breaks down. However, against this break down is a protective counter movement on the part of the society, which takes the form of continuous social (political) interventions to curb the extension of the market. (Polanyi 1944, 132-33). And the result was that "the nineteenth century civilization has collapsed" (Polanyi 1944, 3).

The institutional structure of the "disembedded" economy, i.e. the "self-regulating" market, presupposes the three "fictitious commodities", namely, labor, land and money, all of which must be subjected to sale in the market for the system to function. However, creation of markets for them is of important consequences for the society, because what the term "raw materials" indicate is nothing but nature itself, whereas what we call labor is the whole human life activity. But since these commodities are necessary for the functioning of the system, the very livelihood of individuals and indeed the whole of the society has become dependent upon the market. Under such a system human beings for their own existence need to buy commodities on the market with the incomes they earn by selling other commodities they could offer for sale, including their own labor power and natural environment, land (Polanyi 1947, 97). In other words, the desire of gain and the fear of hunger are the "universal motives", for these two motives are the main drives for human beings to earn incomes, in order to survive, in a market economy. This market society, the society which is "embedded" in or becomes subordinate to the market economy (Polanyi 1977, 9), was an "economic society" in the full sense of the term: Not only are the social classes identical with "supply" and "demand" for the markets for labor, land and capital, but all institutions existing in the society, including family, organization of science and education, and of religion and arts, in short every aspect of life, must conform to the requirements of the market (Polanyi 1947, 100). The immediate corollary of this is, of course, the "market mentality" with its postulate, the notion of economic "rationality." Once a human being is reduced to an "individual in the market" (Polanyi 1977, 29), i.e., to Homo Oeconomicus, it was now easy to argue that "economic" action "was "natural' to man and was, therefore, self-explanatory" (Polanyi 1977, 14). That is, from now on, the term "economic" could safely be identified with the market activity.

The most significant aspect of this institutional change, above all creation of the labor market, is the separation of man from his own life activity itself because "labor" is nothing but the whole human activity which cannot be separated from life. To put this activity under the rule of the market, by making it subject to the fear of hunger, then, will mean nothing less than the breaking down of the "totality" of the life itself. Human life activity is now broken down into specific compartments, such as economic, political, religious, etc., and only the "economic" motives, namely the fear of hunger and hope of gain, are allowed to govern individuals' lives; all other motives, which are usually considered as typical motives affecting every-day lives of human beings, such as honor, pride, solidarity, moral duties and obligations, are regarded as irrelevant to the everyday activities, and forced to gain an esoteric nature, summed up by the word "ideal," since they cannot be relied upon to conduct in the production process (Polanyi 1947, 100-101). 
The most immediate effect of the commodification of labor is the dissolution of the society into "atoms," each of which only behaves in accordance to the motive of the profit and the fear of starvation irrespective of the other members of the society. This, as a result of the application of the principle of freedom of contract, would in practice mean that the noncontractual organization of kinship, neighborhood, profession, and creed, the traits that characterize early, precapitalistic forms of society, "were to be liquidated since they claimed the allegiance of the individual and thus restrained his freedom." (GT, 163). That is to say, labor contract is the manifestation of the "freedom" from the social bond, so that the threat of hunger becomes an individual phenomenon forcing human beings to sell their labor power in the market. On the other hand, regarding the other fictitious commodity, land, this process of disintegration of the society is also a process of separation of human life activity from the natural setting within which it takes place, for it is reduced to a commodity. The result of this "dehumanization" process within which human beings were separated from the very attributes that define their "humanity", was the fact that the relations between human beings lose their direct, personal character for they are reduced to relations between "atoms." But this could not go on forever because it was contrary to the human nature: "Human relationships are the reality of society. In spite of the division of labour they must be immediate, i.e. personal... (H)uman society will be real, for it will be humane: a relationship of persons" (Polanyi 1935, 375-76).

The threat that the system posed for the society as a whole had to call for the "self-protection" of the society from "annihilation"; since such a system, and its result, the subordination of the society to the market, violates the essential features of humanity, and destroys both human and natural substance of the society, it should not be any surprise for society as a whole to try to protect itself against these destructive forces of the market. That is to say, the disintegration of the nineteenth century civilization in the form of fascism, was due to a "double movement", which refers to the struggle between the expansion of the market on the one hand and the "self-protection" of society on the other. As will be seen below, it was the existence of this self-protection which was responsible for the rise of fascism and, indeed, all kinds of "collectivist" attempts. But in order to understand full implications of this process, we need to consider the social theoretical position underlying Polanyi's analysis.

\subsection{Polanyi's "Societal" Perspective}

According to Polanyi, the institutional separation between the economic and political spheres is "merely the restatement, from the point of view of society as a whole, of the existence of a selfregulating market" $(G T, 71)$. This dichotomy presupposed four institutions, two of which were economic in character and the remaining two were political: while the self-regulating market and the gold standard formed the economic sphere, the "liberal" state and the balance of power system formed the political. However, since the self-regulating market is the dominant institution within this setting, all other institutions, namely the gold standard and the balance of power system within the international sphere, and the state within the domestic, to use another taxonomy, must be at the service of the market institution $(G T, 3)$. That is to say, these three institutions are to be characterized by their functionality: They exist by virtue of their roles in facilitating the working of the market smoothly.

Polanyi continuously emphasizes the fact that in the emergence of such an institutional structure, the role of conscious design was crucial. The market economy as a "project," designed by the liberals and implemented by the state interventions, is a prevalent theme throughout The Great Transformation. According to him, "( $\mathrm{t}$ )here was nothing natural about laissez-faire; free markets could never have come into being merely by allowing things to take their course" $(G T, 139)$. An "enormous increase in continuous, centrally organized and controlled interventionism" was necessary, in order to "make Adam Smith's 'simple and natural liberty' compatible with the needs of a human society" (GT, 140). To this end, the most suitable means was the state. In fact, the significance of the state in the establishment of the market system with continuous and conscious interventions was actually one of the cornerstones of the liberal doctrine itself:

Of the three things needed for economic success -inclination, knowledge, and powerthe private person possessed only inclination. Knowledge and power, Bentham taught, 
can be administered much cheaper by government than by private persons. It was the task of the executive to collect statistics and information, to foster science and experiment, as well as to supply the innumerable instruments of final realization in the field of government. Benthamite liberalism meant the replacing of Parliamentary action by action through administrative organs $(G T, 139)$.

Nevertheless, these remarks should not make us think of the whole system as an intentionally devised, giant "conspiracy" against humanity; for Polanyi, the process of establishment of the system were a mix of both intended and unintended results, which were at constant interaction with each other. For example, in his argument that the market economy was a "stark utopia" $(G T, 3)$, he argues that "(i)t was an illusion to assume a society shaped by man's will and wish alone.... The radical illusion was fostered that there is nothing in human society that is not derived from the volition of individuals and that could not, therefore, be removed again by their volition $(G T, 257-58)$. The liberal vision envisaged a "utopia" because liberal thinkers could not foresee the consequences of the actions they recommended: since the market economy was inhumane in the sense that it requires the separation of human beings from their environment and from their own life activity, and hence poses a threat of destroying of the very social fabric, the "self-protection" of the society would inevitably be on the way. From this argument, it is possible to infer that the process within which the market economy developed has rather been a "two way" process in the sense that both intentional actions and their unintended consequences had played a significant role.

As an example to the interaction between intended and unintended consequences of intentional action, one should recall Polanyi's comments on the Speenhamland period. This period between 1795 and 1834, which was an attempt at creating a "capitalism without a labor market" (GT, 124), a contradiction in terms, characterizes a clash between the two opposing tendencies working at the same time: one capitalistic, forcing the poor to sell their labor, and other paternalistic, which deprives their labor of its market value $(G T, 80)$. While the Speenhamland Law was designed to prevent the "proletarianization of the common people, or at least slow it down," the result would be the opposite of what had been intended; it caused to the "pauperization of the masses, who almost lost their human shape in the process" $(G T, 82)$, because it depressed wages even below the subsistence level $(G T, 97)$. Therefore, the abolishment of the Speenhamland system and the establishment of the labor market, by distinguishing the helpless poor whose place was the workhouse and the laboring poor who offered his labor for sale, were to prove financially beneficial to all ( $G T$, 77).

In other words, Polanyi's account should not be treated as a purely "voluntarist" one, for it allows a dynamic interaction between ideas and the material conditions within which these ideas are effective. For example, in another context, Polanyi $(1946,280)$ argues that the social revolution in England was made possible by an "English way" of social action "which subordinates thought to life, and seeks to find solutions in life itself. If one only tries long enough, questions may spontaneously resolve themselves..." Such a notion of the "subordination of thought to life" can be conceived as lying in the framework of what Anthony Giddens calls the "double hermeneutic." On this conception, the social world is constituted by both the actions of the actors and the "metalanguages" invented by the social sciences (Giddens 1984: 284, Özel, 2003). In other words, social science is not only affected by society, but at the same time an effective agent in shaping society; that is, social science is internal to its "subject matter" in a way natural science is not. On the basis of this conception, one can argue that social science, especially political economy, had played a significant role in the development of capitalism. Political economy in the nineteenth century, or in the twentieth for that matter, has been both a reflection of the market relations, of the newly emerging independent economic sphere, and an active participant of production and reproduction of these relations. Polanyi is aware of this:

Laissez faire meant to Bentham only another device in social mechanics. Social not technical invention was the intellectual mainspring of the Industrial revolution.... The triumphs of natural science had been theoretical in the true sense, and could not 
compare in practical importance with those of the social sciences of the day. It was to these latter that the prestige of science as against routine and tradition was due, and, unbelievable though it may seem to our generation, the standing of natural science greatly gained by its connection with the human sciences. The discovery of economics was an astounding revelation which hastened greatly the transformation of the society and the establishment of the market system, while the decisive machines had been the inventions of uneducated artisans some of whom could hardly read or write. It was thus both just and appropriate that not the natural but the social sciences should rank as the intellectual parents of the mechanical revolution which subjected the powers of the nature to man $(G T, 119)$.

Therefore, by allowing a dynamic interaction between "science" and its "subject matter," it is possible to avoid "voluntarism": although the process was a "reflexively monitored" one, to use Giddens's term, it has also been carried out by the social dynamics independent of the individuals and their intentions. Nevertheless, this should not be taken to imply that Polanyi's conception of society is a "holistic" one, which denies the individual and its actions as proper units of social science. For Polanyi it is essential to avoid reifications, i.e., converting human properties into abstract entities, like regarding society as something completely independent from or above the individuals, as Polanyi himself put:

How is a society conceivable which is not a relationship of persons? This implies a society which would not have the individual as its unit. But in such a society, how can economic life be possible if neither co-operation nor exchange -both personal relationships between individuals - can take place in it? How can power emerge, be controlled, and directed to useful ends, if there exists no individuals to express their wills or wishes? And what kind of human being is supposed to populate this society if this being is to possess no consciousness of itself and if its consciousness is not to have the effect of relating him to his fellows? In human beings endowed with the type of consciousness we know such a thing seems frankly impossible. (Polanyi 1935, 371)

Escape from this reification is essential if one wants to avoid some positions, such as "functionalism" and "structuralism", that give quite a limited role for the individual agency. In this regard, it is possible to suggest that Polanyi's position is very close to the conception of the "duality of structure," which states that "the structured properties of social systems are simultaneously the medium and outcome of social acts" (Giddens 1981, 19; Bhaskar 1979). On this conception, societies or social systems cannot exist without human agency, but nevertheless it is not the case that actors create social systems; they reproduce or transform them, remaking what is already made in the continuity of praxis (Giddens 1984, 25). In other words, structures always both constrain and enable intentional human action, yet their production and reproduction are the "unintended consequences" of this intentional action. Even though this gives us a sketch of how the social institutions and structures are reproduced, it should be stressed that this reproduction requires active practices of individuals, or the "positioned practices," again to use Giddens' term, which requires the conceptualization of the society as constituted by real individuals who are at constant interaction with each other.

Actually, it is this impossibility, impossibility of separating individuality from sociality, that is essential for Polanyi's conception of human nature; human beings, for him, are defined by the unity of individuality and sociality: the discovery of the individual is the discovery of mankind. The discovery of the individual soul is the discovery of community. The discovery of equality is the discovery of society. Each is implied in the other. The discovery of the person $i s$ the discovery that society is the relationship of persons. (Polanyi 1935, 370)

In short, Polanyi's conception of the human condition, which is the basis of his critique of capitalism, requires a conviction that human beings are social beings, even though this never implies that they are not individuals at the same time. A human being is characterized by the unity of sociality 
and individuality, the two inseparable characteristics of the human condition, a unity which is broken down in the market society.

According to Polanyi, only within such a "societal" perspective (Dalton 1968), whose outline was given above, can the rise of fascism be understood. An essential ingredient of this "societal" perspective is the notion of the "double movement," as referring to the institutional tendencies within the system, to be conceived in a broad perspective within which all the agents existing in the society interact with each other. The double movement denotes the struggle between the "two organizing principles in society", namely, the principle of economic liberalism and the principle of social protection. While the former aimed at the establishment of the self-regulating market, used free trade as the appropriate method for this aim, and relied on the support of the trading classes, the latter aimed at "the conservation of man and nature as well as productive organization", relied on "the varying support of those most immediately affected by the deleterious action of the market -primarily, but not exclusively, the working and the landed classes" and used "protective legislation, restrictive associations, and other instruments of intervention as its methods" $(G T, 132)$. The double movement works at two distinct yet related levels: the class level, for the social classes, above all the working class, are the causal agents who actually carry out the protective countermovement, and the institutional level, for the protectionist countermovement caused the strains in the institutional structure of the market system, which eventually led to the catastrophe. These two angles, the interaction between the institutional strains inherent in the market system and the conflict of classes, are essential in understanding the catastrophe, i.e. fascism. (GT, 134).

The institutional strains that had arisen in the organization of the market system as a result of the protectionist countermovement, are, according to the institutional spheres they belong, unemployment for the domestic economy, tension of classes for domestic politics, pressures on exchange rates for the Gold Standard, and the imperialist rivalries for the Balance of power system, respectively. $(G T, 209)$. All of these conditions characterize the crisis of the capitalist "world order," the result of which would have been the "collapse" of the system out of which fascism came as a "solution." In this regard, Polanyi identifies two factors as the sources of these disruptive strains: First, the conflict between international and national spheres within the market system, for the functioning of the system required the gold standard and the balance of power at the international level which both demand that the domestic economy and politics must be at the their service, thereby negating the popular and nationalist considerations, and, second, even more important, the institutional separation of the economic and political, for the tensions between the social classes created in the market sphere sooner or later had to be transferred to the political sphere, which in turn creates further problems in the market. That is to say, "since society was made to conform to the needs of the market mechanism, imperfections in the functioning of that mechanism created cumulative strains in the body social" $(G T, 201)$. In other words, the process of double movement will tend to break the institutional separation of the economic and political upon which the market system is built. Here Polanyi emphasizes that the strains in the markets for the three fictitious commodities, labor, land, and money, "would transcend the economic zone and the balance would have to be restored by political means. Nevertheless, the institutional separation of the political from the economic sphere was constitutive to market society and had to be maintained whatever the tension involved." $(G T, 218)$. Therefore, fascism should be seen as a way to reestablish this institutional separation, albeit with brutal force. But such a "solution" could be reached at the expense of the annihilation of all democratic institutions, a fact that shows the degenerative character of fascism: fascism "offered an escape from an institutional deadlock which was essentially alike in a large number of countries, and yet, if the remedy were tried, it would everywhere produce sickness onto death" $(G T, 237)$. According to Polanyi, in the emergence of fascism, the condition of the market system played the essential role: "fascism, like socialism, was rooted in a market society that refused to function" (GT, 239).

Therefore, what fascism, or any kind of "collectivism" for that matter, signifies for Polanyi is the disintegration of the market society itself, which was the result of the double movement. Here, however, one important point to be emphasized is that the protectionist countermovement was not 
the result of some conscious design. It was purely spontaneous, an unconscious process arising out of the resistance of individuals to the market dominating their every-day lives. In other words, contrary to the beliefs of the liberals, definitely to those of Hayek as we will see shortly, there was no "collectivist" conspiracy which aimed at destroying the market by intervening into it: "While laissez faire economy was the product of deliberate state action, subsequent restrictions on laissez faire started in a spontaneous way. Laissez faire was planned; planning was not" $(G T, 141)$. In other words, the collectivist movement needs to be conceived as an unintended consequence of the liberal attempt to form an "economic", i.e., a "market" society. In other words, the proposition that it is impossible to shape a society "by man's will and wish alone" for the whole process is not an outcome of conscious individual behavior, even though it presupposes such behavior, is a useful one in explaining the market system. In order to understand the importance of this point, however, we should consider Hayek's arguments.

\section{Hayek's The Road to Serfdom}

\subsection{The "Spontaneous Order" and the Critique of Collectivism}

Just like for Polanyi, for Hayek too, fascism needs to be conceived as the destruction of the market society, at least an attempt at such a destruction. According to Hayek, National socialism is a "counter-Renaissance," and he argues that National socialism "was the decisive step in the destruction of that civilization which modern man had built up from the age of the Renaissance and which was, above all, an individualist civilization" $(R S, 17)$ For him, the Western civilization is characterized by "liberalism and democracy, capitalism and individualism, free trade and any form of internationalism or love of peace" $(R S, 26)$. However, unlike Polanyi, he believes that such a phenomenon is actually a result of the "protectionist" tendencies which were products of conscious design, especially by the state.

Hayek considers The Road to Serfdom as a warning against those who would be inclined to the view that protectionist interference with the working of the market is necessary, as can be seen from the dedication of the book to "the socialists of all parties." He maintains that such people cannot see "that the unforeseen but inevitable consequences of socialist planning create a state of affairs in which, if the policy is to be pursued, totalitarian forces will get the upper hand" ( $R S$, xlii) thereby destroying individual freedom. That is to say, contrary to Polanyi who sees the market economy as a "utopia," socialism itself, to be conceived as a means to achieve freedom, is "The Great Utopia" (RS, ch. 2).

Hayek's criticisms are directed against collectivism, or more appropriately against the belief that a central planning authority is necessary in order for an economic system to function efficiently. These criticisms can be classified under two interrelated headings. First, in a complex society such as ours, a central planning agency cannot solve the coordination problem, that is, the task of accomplishing compatibility between the optimal plans of different individuals. The reason for this is that in a context of scarcity and the dispersion of knowledge among individuals, a central agency cannot have all the information relevant to the working of the system in an efficient manner for the optimal allocation of scarce resources. Only within a market system, can the coordination problem be solved without any outside intervention, and without any conscious attempt. The second heading of criticisms is that even though such an agency may have the potency to affect economic affairs, this potency should not be called for because to do so will invariably result in violation of individual freedom and hence in creation totalitarian tendencies, no matter how limited the intervention is. The reason for this is that such an intervention is necessarily coercive, forcing individuals to those kinds of behavior which may disturb their plans. Both of these arguments, it should be emphasized, is exclusively founded on the idea of the "spontaneous order," or the unintended consequences of intentional individual action. Here, in respect of the first type of argument, the working of the market system is conceptualized as a spontaneous order based on individual plans while in respect of the second, the coercive action of the state will have, by its very nature, the consequence of restriction, 
if not a complete annihilation, of personal freedom, in a way even unintended by those individuals who would guide the action of the state, no matter how "noble" their intentions are. ${ }^{6}$

As to the first argument, one should bear in mind that Hayek is a methodological individualist par excellence, as opposed to what may be called an "ontological individualist" position, which claims that society is composed only of individuals and this necessitates an individualist position for an appropriate understanding of society. According to Hayek, when the essential characteristics of individualism are considered,

the first thing that should be said is that it is primarily a theory of society, an attempt to understand the forces which determine the social life of man, and only in the second instance as a set of political maxims derived from this view of society. This fact should by itself be sufficient to refute the silliest of the common misunderstandings: the belief that individualism postulates (or bases its arguments on the assumption of) the existence of isolated or self-contained individuals, instead of starting from men whose whole nature and character is determined by their existence in society. If that were true, it would indeed have nothing to contribute to our understanding of society. But its basic contention is quite a different one, it is that there is no other way toward an understanding of social phenomena but through our understanding of individual actions directed toward other people and guided by their expected behavior. This argument is directed primarily against the properly collectivist theories of society which pretend to be able directly to comprehend social wholes like society, etc., as entities sui generis which exist independently of the individuals which compose them. (Hayek 1946, 6)

According to Hayek, such an individualism founds its origins in the eighteenth century British tradition characterized by the thought of David Hume, Bernard Mandeville, and, above all, Adam Smith. ${ }^{7}$ This individualism is not only the true alternative to the collectivist social theory, but it is even drastically different from an "individualism" of the Cartesian school emphasizing the Reason, with a capital $R$, which is thought to be able to shape the society suitable to man's needs, a view which forms foundation of the radical French Enlightenment thought. Contrary to this latter position, Hayek maintains that "human reason, with a capital R, does not exist in the singular, as given or available to any particular person, as the rationalist approach seems to assume, but must be conceived as an interpersonal process in which anyone's contribution is tested and corrected by others" (Hayek 1946, 15). In other words, in respect of individual agents, it should be stressed that "all man's mind can effectively comprehend are the facts of the narrow circle of which he is the center, that, whether he is completely selfish or the most perfect altruist, the human needs for which he can effectively care are an almost negligible fraction of the needs of all members of the society" (Hayek 1946, 14). Therefore, since at a given instance knowledge is dispersed among the members of society and each human being could have only some limited portion of the knowledge as to the working of the society, it is an illusion to assume that a particular individual can comprehend the full extent of the society by his own reason, unless there is an agency which promises to gather and organize all the necessary knowledge. ${ }^{8}$ In such a context, the importance of the market as a coordinating agency arises because,

\footnotetext{
${ }^{6}$ In this regard, Hayek says: "That socialism can be put into practice only by methods of which most socialists disapprove is, of course, a lesson learned by many social reformers in the past" $(R S, 151)$

${ }^{7}$ However, Jeremy Shearmur (1986), challenges this belief and argues that this tradition is not as much important for Hayek's views as he thinks.

${ }^{8}$ Part of the argument here is based on the recognition of the hermeneutical character of society. That is, the "facts" of social sciences are not given, they have to be reconstructed through introspection; these composite "facts" can be known through interpreting in terms of analogies from our own mind. If an individual has only an insignificant portion of the information necessary to understand the social processes, then the knowledge of such processes require the category of interpretation. According to Hayek, "the so-called 'facts' are rather precisely the same kind of mental models constructed
} 
it gives an answer to the central question of economics, and, indeed, of all social sciences: to understand the social "order" arising out of independent, decentralized individual behavior. And to find an answer to this question requires to "show that in this sense the spontaneous actions of individuals will, under the condition which we can define, bring about a distribution of resources which can be understood as if it were made according to a single plan, although nobody has planned it" (Hayek 1937, 54). The existence of a competitive market as an overall coordination agency is an appropriate answer for this question because the market combines and conveys all the piecemeal information, through prices, without invoking of any kind conscious intervention, like that of the state (Hayek 1945). An essential part of Hayek's argument here is that the market, and its basic characterizing disposition, competition should be understood as a process: what we call equilibrium is not just a state of rest of the system at a given point in time; it requires individual plans to be mutually compatible and, consequently, the emergence of "a conceivable set of external events which will allow all people to carry out their plans and not cause any disappointments" (Hayek 1937, 40). These adjustments must be made continuously, for the relevant information that individuals have constantly changes. Then, it is easy to understand why a central planning authority cannot be a proper coordinating agency: No central planner can know these dispersed and constantly changing information by itself in every instance. Therefore, any society that uses central planning cannot solve the economic problem efficiently; only the market, through competition, solve the problem of the mutual compatibility of individual actions based on their plans. If this is the case, it is quite straightforward to argue that the working of this institution must not be hampered by an outside intervention. ${ }^{9}$

On the other hand, as a second type of argument, Hayek argues throughout The Road to Serfdom that state interventions into the working of the market pose a great threat to individual freedom. The alternative for the refusal to submit to the spontaneous order is to submit to the central authority; and while the former secures personal freedom, the latter will result in the annihilation of this freedom. According to Hayek, the erroneous rationalism which refuses to recognize the importance of the market as a coordinating agency fails to see that, unless this complex society is to be destroyed, the only alternative to submission to the impersonal and seemingly irrational forces of the market is submission to an equally uncontrollable and therefore arbitrary power of other men. In his anxiety to escape the irksome restraints which he now feels, man does not realize that the new authoritarian restraints which will have to be deliberately imposed in their stead will be even more painful. $(R S, 224)$

It should not be forgotten that, according to Hayek, the moral values associated with the western civilization, among which individual freedom comes in the first place, are the product of the market, to be conceived as a spontaneous order coordinating individual plans and actions. Then, any kind of conscious attempt to plan the working of the system will invariably result in the restriction of personal freedom and hence even the destruction of the morals which are the product of this very freedom. With respect to the importance of the freedom of choice Hayek argues that the direction of social development in the modern European history "was one of freeing the individual from the ties which had bound him to the customary or prescribed ways in the pursuit of his ordinary activities" (RS, 1819), and that this could only be achieved through the realization of the fact that purely spontaneous behavior of individuals is capable of producing a free growth of economic activity:

Only since industrial freedom opened the path to the free use of knowledge, only since everything could be tried -if somebody could be found to back it at his own risk- and, it should be added, as often as not from outside the authorities officially entrusted with the cultivation of learning, has since made the great strides which in the last hundred and fifty years have changed the face of the world. $(R S, 19)$

by us from elements which we find from our own minds as those which we construct in the theoretical social sciences" (Hayek 1943b, 69).

${ }^{9}$ For a recent examination of Hayek's arguments against socialism, see Caldwell $(1997,2004)$. 
However, the argument that state interventions in the form of conscious planning will be harmful to the working of the market does not necessarily imply a dogmatic laissez faire attitude, that is, the state need not necessarily be completely inactive. On the contrary, it has a very important function: to determine "a carefully thought-out legal framework" $(R S, 41)$, especially concerned with the precise definition of property rights, within which the market operates. Among certain kinds of government actions to protect competition are an "adequate organization of certain institutions like money, markets, and channels of information" and, above all, organization of an "appropriate legal system, a legal system designed both to preserve competition and to make it operate as beneficially as possible." $(R S, 43)$. Therefore, the liberal, far from defending an extreme laissez faire position, must have the attitude toward society "like that of the gardener who tends a plant and, in order to create the conditions most favorable to its growth, must know as much as possible about its structure and the way it functions," and this requires an "increasing intellectual mastery of the forces of which we had to make use" $(R S, 22)$. But beyond this, state action aiming at governing the economic life itself is not admissible, because not only that it will result in an less than efficient allocation of resources, but also that, even more importantly, it will restrict the choices open to individuals and therefore violate personal freedom. In short, it is clear that the philosophy of individualism requires the conception that man is essentially selfish or egoistic. Individualism according to Hayek presupposes that an individual's power of imagination is limited and therefore a comprehensive scale of values that applies to the whole of society is impossible to form; there exists only partial scales of values which may not, and generally are not, consistent with each other. This, on the other hand implies that the individuals should be allowed, within defined limits, to follow their own values and preferences rather than somebody else's; that within these spheres the individual's system of ends should be supreme and not subject to any dictation by others. It is this recognition of the individual as the ultimate judge of his ends, the belief that as far as possible his own views ought to govern his actions, that forms the essence of the individualist position. $(R S, 66)$

Because of the existence of these partial scales of values, the best way for the market to function is freedom. That is, there is a one to one correspondence between freedom and the market; each presupposes the other. Then, it should be obvious that the market actually protects individual freedom for its very existence depend on it.

\subsection{The "Market Mentality" in Hayek}

The above discussion can reveal the similarities and the differences of Hayek's social theoretical position with that of Polanyi, as the table (1) shows.

Regarding this comparison, first of all, one can contend that Hayek defends almost every single point that Polanyi attributes to a liberal. Especially with regard to the market institution, it is startling to observe that both authors see the institutional structure of capitalism in the same way, terminological differences notwithstanding. Not only that the functioning of the market requires some specific institutions like markets and money, but also, even more importantly, that the state itself must be at the service of the market, by defining and protecting the legal framework which designates the boundaries of private property.

In this regard, it should be emphasized that Hayek too gives a role, however limited, to conscious design, not in the functioning of the system, but in defining this very framework within which the market has to operate. In other words, just like Polanyi, Hayek is aware of the existence of the "double hermeneutic," that is, the social science is an active agent in the constitution of its "subject matter," the society. ${ }^{10}$

However, as to the unintended consequences, there is a very important distinction between them. For Hayek, the market is a process which arises spontaneously, as a by-product of intentional individual behavior even though it has a different ontological status from such behavior. That is, it exists and

\footnotetext{
${ }^{10}$ As to the double hermeneutic, what Milton Friedman says in the Introduction to the Fiftieth Anniversary Edition of The Road to Serfdom is quite illuminating: "There is little doubt that Hayek's writings, and especially this book, were an important intellectual source of the disintegration of faith in communism behind the Iron Curtain' as on our side of it" (p. xix). In other words, Hayek's arguments in the book has become "self-fulfilling prophecies" in the above sense.
} 
act by virtue of individual behavior but no single individual intends to create such an institutional framework. More crucially, Hayek maintains that such a spontaneous order will always create socially desirable outcomes, both in terms of efficiency and of freedom, whereas any conscious attempt to create an order based on design will invariably result in undesirable outcomes, especially if it is tried to be comprehensive enough to include the whole of the society. On the other hand, for Polanyi, historically speaking, the market was the product of conscious design whereas the "collectivist" countermovement was purely spontaneous even though it operates through individual behavior. It is this countermovement which is in the interest of the society as a whole for otherwise it would be "annihilated" in the sense that the relations between individuals lose their direct and "human" character. I will return to this issue shortly but before this, an evaluation of Hayek's conception of the unintended consequences is in order.

Table 1 : THE MARKET SYSTEM IN HAYEK AND POLANYI

\begin{tabular}{|c|c|c|}
\hline & HAYEK & POLANYI \\
\hline Main Issue & $\begin{array}{l}\text { Freedom in a "complex } \\
\text { society", }\end{array}$ & $\begin{array}{l}\text { Freedom in a "'complex } \\
\text { society", }\end{array}$ \\
\hline İnstitutional Structure & $\begin{array}{l}\text { Separation of the Economic } \\
\text { from the Political }\end{array}$ & $\begin{array}{l}\text { Separation of Economic } \\
\text { from the Poliical }\end{array}$ \\
\hline Creation Mechanism & $\begin{array}{l}\text { 'spontaneous order"' (no } \\
\text { design): Unintented } \\
\text { consequences }\end{array}$ & $\begin{array}{l}\text { Conscious design (state } \\
\text { intervention interacting } \\
\text { with unintended } \\
\text { consequences) }\end{array}$ \\
\hline Maintenance of the Institutional Structure & $\begin{array}{l}\text { By conscious design (state } \\
\text { action for protecting the legal } \\
\text { framework) }\end{array}$ & $\begin{array}{l}\text { By conscious design (state } \\
\text { action for protecting the } \\
\text { overall institutional } \\
\text { structure) }\end{array}$ \\
\hline Consequence of the System & $\begin{array}{l}\text { Socially desirable outcomes } \\
\text { (efficient allocation and } \\
\text { freedom) }\end{array}$ & $\begin{array}{l}\text { "dehumanization", } \\
\text { (violation of sociality and } \\
\text { freedom) }\end{array}$ \\
\hline Cause and Effect of "Collectivism"' & $\begin{array}{l}\text { Conscious design } \rightarrow \text { fascism: } \\
\text { violation of freedom }\end{array}$ & $\begin{array}{l}\text { Spontaneous (protectionist } \\
\text { countermovement) } \rightarrow \\
\text { fascism }\end{array}$ \\
\hline
\end{tabular}

\section{Source: The Author}

If Hayek's main contribution is to be understood as to point out that "in an environment of scarcity in which information is disaggregated or dispersed, the price-system is a low-cost mechanism for its aggregation and transmittal" (Caldwell 1997, 1877), the strength of his argument depends exclusively on the plausibility of the hypothesis of unintended consequences, for the whole burden of Hayek's argument is carried by this hypothesis. Then, it is appropriate to ask whether or not the idea of unintended consequences is strong enough to fulfil this function. Unfortunately, this is not so in Hayek's case. Given his dislike of formal general equilibrium models (Hayek 1937, 1945), for they cannot consider competition as a process, it is hard to say that Hayek has given an explanation about, first, how this mechanism really works, and, second, why such a process always create socially 
desirable outcomes. In other words, unintended consequences is used as an explanan which itself needs to be explained. The implausibility of such a reasoning would become transparent if we consider Hayek's position that the main function of the market is to combine piecemeal information. Without giving an explanation about how it came into existence in the first place, such an argument reduces to a functional one: the market exists by virtue of its being functional in solving the coordination problem. That is to say, Hayek unintentionally paints himself into the corner of functionalism, for he seeks the "explanation" of the working of the market in its function to convey piecemeal information, as if it was designed intentionally. But when he also asserts that the institution in question emerges spontaneously, then such a functional argument loses its strength. ${ }^{11}$ Actually, there is a tension in Hayek's arguments here, a tension which could be fatal for his entire reasoning: On the one hand he admits the importance of the state and its designing role in the working of the market, especially in defining and maintaining an appropriate legal framework, while on the other he excludes any role played by design in the working of the market within this legal framework. But such a reluctance of admitting the importance of design causes his whole analytical structure to become weaker.

Alternatively, Polanyi's argument too has a strong functionalist tendency: in order for the market economy to function properly, not only must the commodity fictions be created and sustained, but even the social and political institutions (i.e., the state, the gold standard, and the balance of power system) must be at the service of the market; all social institutions are determined by the "needs" of the market system. Yet, if one accepts with Polanyi that the market economy was created by such a deliberate design, functionalist explanation makes sense. In other words, since it is possible to assert that this economy functions as if it were designed intentionally, functional questions can be quite useful in understanding the system.

This brings us to the second problem in Hayek's conception of the unintended consequences. As we have just seen, Hayek simply accepts it as an explanatory mechanism at the most abstract level and develops his theses on the basis of this mechanism. However, contrary to his wishes, his reasoning here still presupposes a "representative individual" by whose behavior the whole mechanism emerges. That is to say, Hayek is not willing to consider the asymmetries that can arise in behavior of different individuals having different backgrounds, different social status, and different class origins. Depending on the status of the individual within the overall social system of stratification, his or her response to the same impulse may vary. For example, in Polanyi, different individuals coming from different classes respond differently to the same phenomenon, the establishment of the market institution. While one class who in general favor the establishment of the market will take side with the extension of it, the other, whose very existence is in danger that is posed by the market, will try to resist this extension. If this is the case, different intentions will result in different consequences, be them intended or unintended. As the history of fascism has shown, those who resisted the market, namely, the working class and its allies, had "achieved what had been intended: the disruption of the market for that factor of production known as labor power" $(G T, 176)$, whereas the intentions of those who tried to establish and maintain the institutional structure of the market society had the unintended consequence of the disintegration of the whole society. Therefore, so long as Hayek is not willing to take account the importance of the asymmetrical behavior, his mechanism becomes a reification, independent of the individuals constituting the society. That is to say, Hayek's spontaneous order argument once again cannot carry the burden that is imposed on it: even though he is willing to consider individuals' plans and intentions, the fact that his arguments are reduced to functional ones based on the "representative individual" shows that he is not able to resolve the

\footnotetext{
${ }^{11}$ At this point, it could be asserted that Hayek argues in his later works that the spontaneous order is a result of social evolution. Although Hayek's views about evolution does not lie within the scope of the present paper, for in The Road of Serfdom he does not specifically mention evolutionary arguments in favor of the spontaneous order, these views too are not immune to the above criticisms for they rest heavily on functionalist arguments. For a thorough evaluation of Hayek's views on evolution see Hodgson (1993, ch. 12); on the other hand, for the problems associated with the use of evolutionary ideas in social theory, see Giddens (1984, ch. 5).
} 
dilemma between "the Scylla of populating the world with imaginary powers and dominions", and "the Charybdis of reducing everything to the verifiable behavior of identifiable men and women" (Berlin 1969, 54n).

The third problem in Hayek's reasoning in this context, a point which actually constitutes the main difference between the "visions" of Polanyi and Hayek, is that "if one were even able to show that such a Hayekian liberalism represented the best attainable social order, there would still be problems concerning its acceptability to those who actually live within it. For it may not be possible to make its advantages clear to them, and such a society may appear to lack moral legitimacy," as a sympathetic critic of Hayek (Shearmur 1986, 220) formulates. And this is exactly how Polanyi criticizes both the liberal thinkers and their "work," namely the market system. That is, liberalism, presupposes an "economistic" outlook to which we are turning now.

Hayek's arguments in The Road to Serfdom presupposes a particular view about the human condition: it is to be characterized by the ubiquity of scarcity and choice. For Hayek, the people who would wish that "the choice should not be necessary at all" and who "are only too ready to believe that the choice is not really necessary, that it is imposed upon them merely by the particular economic system under which we live" in fact resent "that there is an economic problem" $(R S, 107)$. But such people hold the erroneous belief that there are purely economic ends separate from the other ends of life. Yet, apart from the pathological case of the miser, there is no such thing. The ultimate ends of the activities of reasonable beings are never economic. Strictly speaking, there is no "economic motive" but only economic factors conditioning our striving for other ends. What in ordinary language is misleadingly called the "economic motive" means merely the desire for general opportunity, the desire for power to achieve unspecified ends. $(R S, 98)$

Therefore, what such people forget is that, if human beings are intelligent and rational, they have to solve the economic problem irrespective of the nature of their ends, economic or "noneconomic." In this case, the problem of making choices among alternatives is necessary for every human being. In this regard, it should be stressed that human beings are characterized by their individual freedom for Hayek. If individual freedom is to be conceived primarily as the freedom of choice, then Hayek's argument concerning the working of the market economy can be said to be an argument also for the human condition. That is to say, a market economy is the best system among its alternatives because it conforms fully to the characteristics that define human beings: only within this system can the individual realize his or her freedom and hence affirm his or her humanity. This, as can be seen, constitutes the most significant difference of Hayek's vision from that of Polanyi, who would maintain that the market system creates a "dehumanization" process, as argued above.

From Polanyi's standpoint, what such a proposition in effect amounts to is the fact that the economic sphere governs individuals' lives. In Polanyi's analysis, the immediate effect of the creation of the fictitious commodities is the fact that economic determinism had to dominate our minds within the market society, which is nothing but an "accessory" of the economic system $(G T, 75)$. In other words, the disembedded market economy makes the rule of the "changelessness of man as a social being" $(G T, 46)$ obsolete, for it inevitably leads to the dissolution of the society into "atoms." This implies that Polanyi's notion of the human condition is not primarily given by the economic motives; a notion of the human condition emphasizing the "economic" motives is based upon the failure to distinguish between historically specific and general aspects of the human existence, the consequence of which is ubiquitous economic determinism. This "economistic fallacy," i.e., identification of economic phenomena with market phenomena (Polanyi et al. 1957, 270; Polanyi 1977, 20), or the extrapolation of the categories that are prevalent in capitalism to other societies and/or other times, which has always been the hallmark of the liberal thinking, is therefore merely a product of capitalism.

Such an analytical framework which conceives the market system as consisting of two independent spheres, the economic and the political, informs Polanyi's understanding of fascism, which was, for him, a "social," not economic, "solution" for the functioning of the market system, which denies individual freedom and almost every kind of human spontaneity. But the fascist solution actually characterizes the "collapse" of the society with all institutions that are both expressions and 
means for the affirmation of freedom and hence humanity. In fact, it even signifies the collapse of the whole of a western civilization, for it amounts to the denial of the very values that characterize this civilization. The only way to restore these values for Polanyi is to accept both the "uniqueness of individual" and the "oneness of mankind" (GT, 258A) which indicates two inseparable characteristics that define humanity, which, he thought could be achieved only with socialism, contrary to Hayek.

\section{Conclusion}

The argument of the present paper is threefold: First, although Hayek's and Polanyi's arguments concerning the market economy are almost symmetrically opposite, the underlying socialtheoretical positions adopted by these two thinkers are quite similar, in conceptualizing both the institutional structure of the market system and its working. At a general level, an essential characteristic uniting their respective social theories is the use of the idea of unintended consequences by both writers. However, as the second argument of the paper, such an idea by itself is not strong enough to carry their respective arguments, even though Polanyi's analysis is superior to that of Hayek in that it recognizes the "asymmetries" between different individuals, or different group of individuals coming from different social strata. That is to say, Polanyi gives some descriptions concerning how unintended consequences operates at specific instances and concrete levels, while in Hayek's argument it remains essentially as an abstraction by which everything is explained. But above all, as the third argument of the paper, it is the difference between the respective "visions" of Polanyi and Hayek regarding human beings and freedom that constitutes the essential difference between their understandings of the capitalist society. Whereas for Polanyi human beings are not characterized by that they behave under the guidance of "economic" motives, the fear of hunger and the hope of gain, which should be conceived as violating freedom, Hayek conceives freedom basically as defined within the market sphere, only in the sense of "free enterprise." In fact, it is this divergence between their visions which is unbridgeable, not, definitely, their differences in the handling of the idea of unintended consequences.

\section{References}

Bhaskar, Roy. 1979. The Possibility of Naturalism: A Philosophical Critique of the Contemporary Human Sciences. Brighton: Harvester.

Berlin, Isaiah. 1969. "Historical Inevitability," in Four Essays on Liberty. Oxford, New York:OxfordUniversity Press.

Caldwell, Bruce. 1997. "Hayek and Socialism”, The Journal of Economic Literature, Vol. 35, No.4. pp. 1856-1890.

Caldwell, Bruce. 2004. Hayek's Challenge: An Intellectual Biography, Chicago: Chicago UniversityPress.

Dalton, George. (ed.) 1968. Primitive, Archaic, and Modern Economies: Essays of Karl Polanyi, New York: Anchor Books.

Giddens, Anthony. 1981. A Contemporary Critique of Historical Materialism (vol. 1:) Power, Property and State. London: Macmillan.

Giddens, Anthony. 1984. The Constitution of Society: Outline of the Theory of Structuration. Cambridge: Polity Press.

Gould, Stephen J. and R. C. Lewontin. 1979. "The Spandrels of San Marco and the Panglossian Paradigm: A Critique of the Adaptationist Programme", Proc. B. Soc. Lond. B, Vol. 205, p. 581-98.

Güzel, C. and H. Özel. 2011. "İktisat ve Sosyal Teoride Evrim Düşüncesi, Amme İdaresi Dergisi, Cilt 44, Sayı 3, Eylül, pp. 1-26. 
Hayek, Friedrich A. von. 1937. "Economics and Knowledge," Economica, vol.4; reprinted in Individualism and Economic Order, Chicago: The University of Chicago Press, 1948, pp. $33-56$ (page number references are given to the latter edition).

Hayek, F.A. 1942. "Scientism and the Study of Society, Part I," Economica, vol. 9, no. 35, August, pp. 267-291.

Hayek, F.A. 1943a. "Scientism and the Study of Society, Part II", Economica, vol. 10, no. 37. February 1943, pp. 34-63.

Hayek, Friedrich A. von. 1943b. "The facts of the Social Sciences," Ethics, vol. 54; reprinted in Individualism and Economic Order, Chicago: The University of Chicago Press, 1948, pp. 57-76 (page number references are given to the latter edition).

Hayek, Friedrich A. von $(R S)$. The Road to Serfdom, Chicago: The University of Chicago Press, 1944.

Hayek, Friedrich A. von. 1945. "The use of Knowledge in Society," American Economic Review, vol. 35, no.4, pp. 519-30; reprinted in Individualism and Economic Order, Chicago: The University of Chicago Press, 1948, pp. 77-91 (page number references are given to the latter edition).

Hayek, Friedrich A. von. 1946. "Individualism: True and False," in Individualism and Economic Order, 1948, pp. 1-32 (page number references are given to the latter edition). Chicago: The University of Chicago Press.

Hayek, F. A. 1948. Individualism and Economic Order. Chicago: The University of Chicago Press. Hayek, Friedrich von. 1973. Law Legislation and Liberty. Vol. I. London: Routledge and Kegan Paul. Hayek, Friedrich von. 1976. Law Legislation and Liberty, Vol. II. London: Routledge and Kegan Paul.

Hayek, Friedrich von. 1979. Law Legislation and Liberty, Vol. III. London: Routledge and Kegan Paul.

Hayek, Friedrich von. 1984. "Competition as a Discovery Procedure", Nishiyama, C. - K. Leube (Eds.), The Essence of Hayek, , p. 254-265. Stanford, Ca.: Hoover Institution Press.

Hirschman, Albert O. (1982). "Rival Interpretations of Market Society: Civilizing, Destructive, or Feeble?" Journal of Economic Literature, vol. 20, December, pp. 1463-84.

Hodgson, Geoffrey M. 1991. "Economic Evolution: Intervention Contra Pangloss", Journal of Economic Issues, Vol. 25, No. 2 (June), pp. 519-533.

Hodgson, Geoffrey M. 1993. Economics and Evolution: Bringing Life Back into Economics. Ann Arbor: The University of Michigan Press.

Hollis, Martin. 1994. The Philosophy of Social Science: An Introduction, Cambridge: Cambridge University Press.

Kirman, Alan P. 1992. "Whom or What Does the Representative Individual Represent?", Journal of Economic Perspectives, Vol. 6, No. 2, p. 117-36.

Lewontin, Richard. 1991. "Facts and the Factitious in Natural Sciences", Critical Inquiry, Vol. 18, Autum, pp. 145-46.

Lewontin, Richard. 2007. Üçlü Sarmal: Gen, Organizma ve Çevre, Ankara: TÜBİTAK Popüler Bilim Kitapları.

Little, Daniel. 1991. Varieties of Social Explanation: An Introduction to the Philosophy of Science, Boulder: Westview Press.

Mahner, Martin and Mario Bunge. 2001. "Function and Functionalism: A Synthetic Perspective", Philosophy of Science, Vol. 68, No. 1 (March), p. 75-94. 
Mandeville, Bernard. 1962. The Fable of the Bees, or Private Vices, Publick Benefits, I. Primer (Ed.), New York: Capricorn Books.

Özel, Hüseyin. 1997. Reclaiming Humanity: The Social Theory of Karl Polanyi, Unpublished Ph. D. Dissertation, The University of Utah.

Özel, Hüseyin. 2003. "Closing the Open Systems: Two Examples for the "Double Hermeneutics in Economics," METU Studies in Development, vol. 30, December 2003, pp. 223-248.

Özel, Hüseyin. 2009. “İktisat ve Sosyal Teoride 'Görünmez El' Eğretilemesi,” Amme İdaresi Dergisi, cilt 42, say1 2, Haziran, s. 45-65 (English translation: "The 'Invisible Hand' Metaphor in Economics and Social Theory," TODAIE's Review of Public Administration, vol. 3, no. 2, June 2009, pp. 51-74).

Özel, Hüseyin. 2018. "Four Horsemen of the Apocalypse: Marx, Weber, Schumpeter, and Polanyi," Ylldız Social Science Review, vol. 4, no. 2, pp. 111-24.

Özel, Hüseyin. 2019. "Commodification," in Exploring the Thought of Karl Polanyi, Christopher Holmes, Gareth Dale, and Maria Markantonatou (eds.), London: Agenda Publishing, pp. 131-49, forthcoming.

Polanyi-Lewitt, Kari and Marguerite Mendell. 1989. "The Origins of Market Fetishism," Monthly Review, vol. 41, no. 2, June, pp. 11-32.

Polanyi, Karl. 1935. "The Essence of Fascism" in Christianity and The Social Revolution, J. Lewis, K. Polanyi, D.K. Kitchin (eds.), London: Victor Gollancz Ltd, 1935.

Polanyi, Karl (GT). The Great transformation: The Political and Economic Origins of Our Time. (paperback edition: Boston: Beacon Press, 1957) New York: Rinehart \& Co., 1944

Polanyi, Karl. 1946. "Whither Civilization? British Thinkers Ponder the Atomic Age," Commentary, vol. II, July-December, 280-285.

Polanyi, Karl. 1947. “On Belief in Economic Determinism” The Sociological Review, vol. 39, Section One, pp. 96-102.

Polanyi, Karl. 1977. The Livelihood of Man, ed. by Harry W. Pearson, New York; Academic Press.

Polanyi, Karl, Condrad M. Arensberg and Harry W. Pearson. (eds.) 1957. Trade and Markets in the Early Empires: Economies in History and Theory, New York: The Free Press.

Popper, Karl R. 1950. The Open Society and Its Enemies, Princeton, Princeton University Press.

Rotschild, Emma. 1994. "Adam Smith and the Invisible Hand", American Economic Review, Papersand Proceedings, May, p. 319-322.

Russel, Bertrand. 1945. A History of Western Philosophy. New York: Simon and Schuster.

Sarfati, Metin. 2007. “Smith'de Bütünlük Sorunu”, İktisat Dergisi, Sayı 490, (Ekim-Kasım).s. 32-47.

Shearmur, Jeremy. 1986. "The Austrian Connection: Hayek's Liberalism and the Thought of Carl Menger," in Austrian Economics: Historical and Philosophical Background, W. Grassl and B. Smith (eds.), New York, New York University Press.

Smith, Adam. 1776. An Inquiry into the Nature and Causes of The Wealth of Nations, Edwin Cannan (Ed.), 1976. The University of Chicago Press.

Ullmann-Margalit, Edna. 1997. "Invisible Hand and the Cunning of Reason", Social Research, Vol.64, No. 2, Summer, pp. 181-99. 